\title{
ANAPHYLAXIS WITH SCHISTOSOMA MANSONI EXTRACTS IN NORMAL AND INFECTED MICE
}

\author{
T. A. MOTA-SANTOS (1), A. F. S. OLIVEIRA, S. E. GERKEN (2) and N. M. VAZ (1)
}

\section{S U M M A R Y}

Methods generally utilized for studies on anaphylaxis to protein antigens such as determination of histamine release to the blood, hemoconcentration, histamine release from peritoneal mast cells and passive cutaneous anaphylaxis (PCA) were used to investigate some aspects of the anaphylaxis to parasite antigens in Schistosoma mansoni infected mice. The release of histamine to the blood and significant rates of hemoconcentration were induced by intravenous injection of schistosomula or cercarial extracts into 10-13 weeks infected mice. Cercarial, schistosomula, worm tegument and soluble egg antigens were able to trigger histamine release from peritoneal mast cells from chronically infected mice. In spite of the PCA reaction beeing detected within 2 hours of sensitization ( IgG $_{1}$ antibodies) in 6 of 8 tested sera from chronically infected mice, no detectable reactions were obtained after 48 hours sensitization (IgE antibodies). Although IgE was not detected in the circulation, by the PCA technique, the results indicate that the infected mice contained IgE antibodies bound to their mast cells.

\section{N T R O D U C T I O N}

IgE production is a characteristic feature of helminth infections and it has been suggested. that specific IgE antibodies may be involved in the establishment of protective immunity 1,9 , 19,20 . Quantitation of IgE antibodies in experimental animals and in humans has shown that infection by Schistosoma mansoni is followed by an increase in the levels of IgE antibodies to parasite antigens $7,21,24$.

The participation of sensitizing antibodies in the resistance to schistosome was suggested by the observation 25 that there is an inverse relationship between the level of reaginic antibodies and susceptibility to a primary schistosome infection in several animal species. Among the animals studied, mice were placed at the highest level of susceptibility; they tend to harbour a high percentage of worms derived from a primary infection, and fail to produce reaginic antibodies to cercarial or worm antigens as assessed by the passive cutaneous anaphylaxis technique ${ }^{17}$.

Recent observations have suggested that vasoactive amines play a central role in the resistance of chronically-infected mice to a second challenge-infection with schistosome, strongly suggesting the participation of sensitizing antibodies in the resistance to reinfection ${ }^{8}$. The analysis of anaphylactic sensitization in experimental schistosomiasis is fraught with several problems. Sensitization is caused by contact with whole living parasites in different developmental stages - schistosomula, adult worms, eggs and their secretions - each

(1) Department of Biochemistry-Immunology, ICB-UFMG, Belo Horizonte, MG, Brasil

(2) Department of Parasitology, ICB-UFMG, Belo Forizonte, MG, Brasil

Correspondence: T.A. Mota-Santos - Departamento de Bioquímica-Imunologia, ICB-UFMG, Caixa Postal 2486, 30000 Belo Horizonte - MG, Brasil 
MOTA-SANTOS, T. A.; OLIVEIRA, A. F. S.; GERKEN, S. E. \& VAZ, N. M. - Anaphylaxis with Schistosoma mansoni extracts in normal and infected mice. Rev. Inst. Med. trop. São Paulo 27:179-185, 1985.

of which is a potential source of multiple antigens. Cross-reactivity between antigens of different maturational stages of $\mathbf{S}$. mansoni has been suggested by previous studies ${ }^{4,11}$ and $\sin$ ce common antigens among several parasitic helminths have been reported ${ }^{6}$, there is also the possibility of cross-reactions due to previous or concomitant infections with other worm species common in laboratory rodents.

The present studies were undertaken to evaluate the usefulness of methods previously utilized in the analysis of anaphylaxis to protein antigens in the mouse $15,27,28$ to elucidate problems in this area. We concluded that the methods are applicable and useful.

\section{MATERIAL AND IMETHODS}

Mice

Young adult C57BL/10J mice of both sexes were derived from our own colonies.

\section{Infection with S. mansoni}

Mice were infected by subcutaneous injection of an average of 20 cercariae of $\mathbf{S}$. mansoni (L. E. strain, Belo Horizonte, MG, Brazil) obtained from a pool of Biomphalaria glabrata snails reared in the laboratory. Unisexual infections of some mice were achieved by subcutaneous injection of single sex (male) cercariae obtained from snails individually exposed to single miracidia.

\section{Parasite extracts}

Cercarial extract was prepared by sonication in an ice-bath 10 times, for $1 \mathrm{~min}$, with 1 min intervals. Tegument from adult worms was prepared by freezing and thawing ${ }^{13}$. Soluble egg-antigen was prepared as previously described ${ }^{18}$. Extract from fresh schistosomula ${ }^{23}$ was prepared by sonication for 5 minutes in an ice bath. Whole body extract of Paraascaris equorum was obtained by homogenizing freshly collected worms in saline in a waring blender followed by centrifugation at $5.000 \mathrm{rpm}$ for 1 hour at $4^{\circ} \mathrm{C}$ to remove large debris. The protein content of the extracts was determined by the method of LOWRY et al. 16.

\section{Histamine release to the blood}

Normal mouse blood freshly collected by orbital puncture and directly added to atropinizea guinea pig ileum preparations contain negligible amounis of free histamine and evoked no contractions in the preparation. In contrast large concentrations of histamine appear in the blood soon after intravenous challenge of sensitized mice with the specific antigen and evoked strong contractions in the ileum preparation. A similar burst of histamine release may be induced in normal mice by the intravenous injection of compound 48-80, a known histaminereleaser; by itself, compound $48-80$ has no measurable effect upon the reactivity of the ileum preparation.

Semi quantitative assessments of the mag nitude of histamine release to the blood after injection of $\mathbf{S}$. mansoni extracts into normal or sensitized mice were made by bracketing the stimulations with blood samples with standard stimulations with histamine ${ }^{27}$. Blood samples were collected with Lang-Levy pipettes (H.E. Pedersen, Copenhagen) of 25, 50, 100 or 200 microliters, choosen em. pyrically in each test. As used, the method allowed the assessment of histamine concentrations above 0.05 and below $4.0 \mu \mathrm{g}$ per mililiter of blood plasma (taking the hematocrit arbitrarily as 50). The specificity of histamine action in blood samples of mice injected with worm extracts was confirmed by specific inhi. bition with piribenzamine maleate.

\section{Histamine release from peritoneal mast cells}

Peritoneal cells suspensions containing mast cells were collected from groups of 4 to 6 mice killed by overexposure to ether, after injection of $3 \mathrm{ml}$ of chilled modified-Ringer solution containing $50 \mu \mathrm{g} / \mathrm{ml}$ of heparin 22 an gentle massage. The cells were pooled, divided in aliquo tes, centrifuged $\left(900 \mathrm{~g}, 10\right.$ minutes at $\left.4^{\circ} \mathrm{C}\right)$, resuspended in $0.9 \mathrm{ml}$ of fresh Ringer, shaken and incubated in a water bath at $37^{\circ} \mathrm{C}$ for 10 minutes. The cells were then challenged with $0.1 \mathrm{ml}$ of antigen (extracts) dilutions or $0.1 \mathrm{~m}$ ] of Ringer (controls), incubated for 10 more minutes and centrifuged in the cold. The supernatants were collected for histamine assays, the cell pellets suspended in $1.0 \mathrm{ml}$ of Ringer and placed for 5 minutes in a boiling water 
MOTA-SANTOS, T. A.; OLIVEIRA, A. F. S.; GERKEN, S. E. \& VAZ, N. M. - Anaphylaxis with Schistosoma mansoni extracts in normal and infected mice. Rev. Inst. Med. trop. São Paulo 27:179-185, 1985.

bath for the extraction of the residual histamine; these suspensions were centrifuged and a second (residual) supernatant set of samples collected for assay. Assays were always carried out in duplicates, but the dispersion between them was virtually nil. The magnitude of the histamine released was expressed as the percentage of the total cell histamine, discounting the release observed in control tubes, which ranged from 5 to 17 percent.

\section{Hemoconcentration}

Anaphylactic shock in the mouse is characterized by progressive respiratory distress, cyanosis and edema due to massive plasma leakage from the peripheral circulation, as evidenced by rapid increases in hematocrit rates ${ }^{3}$. An indirect but rapid evaluation of the hematocrit variation in mice undergoing shock may be made by measurement of the hemoglobin concentration in blood sample of 10 microliters collected serially from the orbital sinuses ${ }^{12}$. The blood samples were lysed in $5 \mathrm{ml}$ of $0.1 \% \mathrm{Na}_{2}$ $\mathrm{CO}_{3}$ and read at $541 \mathrm{~nm}$. The magnitude of the hemoconcentration was expressed as a percentage of the increase observed at 5 and $10 \mathrm{mi}$ nutes after intravenous challenge.

\section{Passive cutaneous anaphylaxis}

Passive cutaneous anaphylaxis (PCA) in the dorsal skin of recipient albino Swiss mice was tested 2 and 48 hours after intradermal injections of $0.03 \mathrm{ml}$ of serum dilutions ${ }^{15}$.

Intravenous challenge with cercarial extracts in $0.5 \%$ Evans blue dye was made 20 minutes after reading the reactions in the reverted skins of mice.

\section{RESULTS}

As shown in Table I neither cercarial nor schistosomula extracts were able to induce the release of histamine to the blood of normal uninfected mice, which, however, displayed very strong release upon challenge with $20 \mu \mathrm{g}$ of compound 4880. Essentially the same results were seen when mice infected 4-weeks before were challenged. On the other hand, very strong to moderate release were induced by both extracts when mice infected 13-weeks before were challenged. Similar moderate to very strong release were induced in mice submitted to unisexual infection 10 weeks before.

T A B L E I

Release of histamine to the blood of infected mice after intravenous injection of Schistosoma mansoni extracts

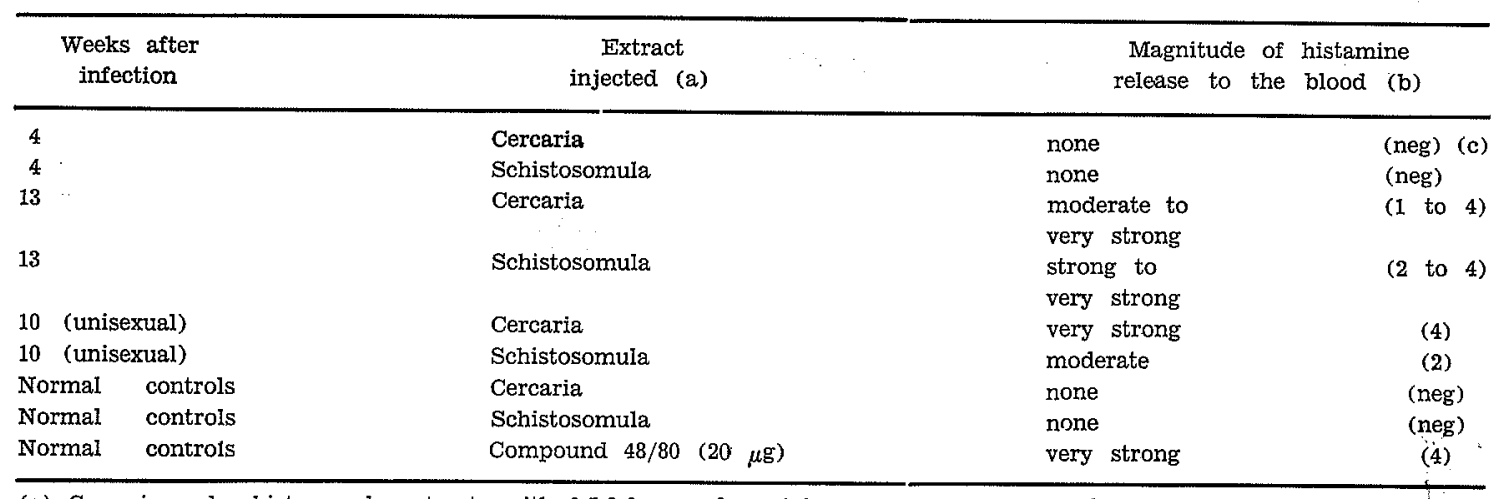

(a) Cercaria and schistosomula extracts with $0.5-0.6 \mathrm{mg}$ of protein per mouse in $0.2 \mathrm{ml} \mathrm{i} . \mathrm{v} \cdot$; (b) Blood samples of 25 to 200 microliters collected at $I$ and/or 3 and/or 6 minutes after challange of at least 3 mice; (c) range of histamine concentration ( $\mu \mathrm{g} / \mathrm{ml}$ plasma; neg $=$ below $0.05 \mu \mathrm{g} / \mathrm{ml}$ )

As shown in Table II S. mansoni extracts were able to induce the release of histamine from peritoneal mast cells from infected mice. The same extracts induced less than 10 percent release of histamine from mast cells of normal uninfected mice (not shown in Table II). With cercarial extracts there was a significant increase of the release ( 5 to $67 \%$ ) in the late phase of the infection (4 to 13-weeks). Extracts of tegument, and soluble egg antigens tested upon 15 weeks infected mice induced moderate levels of release (15 to $28 \%$ ); in these same 
MOTA-SANTOS, T. A.; OLIVEIRA, A. F. S.; GERKEN, S. E. \& VAZ, N. M. - Anaphylaxis with Schistosoma mansoni extracts in normal and infected mice. Rev. Inst. Med. trop. São Paulo 27:179-185, 1985.

cells, whole body extracts of Paraascaris equon rum induced only $5-6 \%$ release.

T A B L E II

Release of histamine from mouse peritoneal mast cells by Schistosoma mansoni extracts

\begin{tabular}{clrc}
\hline $\begin{array}{c}\text { Weeks after } \\
\text { infection }\end{array}$ & \multicolumn{1}{c}{$\begin{array}{c}\text { S. mansoni } \\
\text { extracts (g protein } / \mathrm{ml} \text { ) }\end{array}$} & $\begin{array}{c}\text { Percent net } \\
\text { histamine release (a) }\end{array}$ \\
\hline 4 & Cercaria & 10 & 6 \\
\multirow{2}{*}{13} & Cercaria & 100 & 5 \\
& & 10 & 7 \\
15 & Tegument & 100 & 67 \\
& & 14 & 25 \\
15 & Soluble egg & 14 & 28 \\
& antigen & 140 & 24 \\
& & 14 & 15 \\
\multirow{2}{*}{15} & P. equorum & 140 & 6 \\
& Whole body & & 5
\end{tabular}

(a) Percent release after deduction of control (spontaneous) release (range 5-17\%)

Although unable to induce the release of histamine to the blood of normal mice (Table I) the injection of cercarial extracts induced moderate (1 $\mathrm{mg}$ per mouse) to severe or lethal (10 $\mathrm{mg}$ per mouse) symptoms of shock, and significant rates of hemoconcentration: 13 (with $1 \mathrm{mg}$ ) to $46 \%$ (with $10 \mathrm{mg}$ ) of increase in hemoglobin concentrations. Nevertheless the injection of these same extracts into 13-weeks infected mice induce more severe forms of shock and significantly higher rates of hemoconcentration: 27 and $55 \%$ increase, respectively with 1 and $10 \mathrm{mg}$ per mouse; with $10 \mathrm{mg}$ doses 5 out of 5 mice were killed in 15 minutes or less. The results are shown in Table III.

\section{T A B L E III}

Hemoconcentration after injection of cercarial extracts into normal and infected mice

\begin{tabular}{|c|c|c|c|c|c|c|c|}
\hline \multirow{2}{*}{$\begin{array}{l}\text { Mouse } \\
\text { number }\end{array}$} & $\begin{array}{l}\text { Normal } \\
1 \mathrm{mg} \mathrm{(a)}\end{array}$ & \multicolumn{2}{|c|}{ mice } & \multicolumn{2}{|c|}{$\begin{array}{l}\text { Infected } \\
1 \mathrm{mg}\end{array}$} & \multicolumn{2}{|c|}{$\begin{array}{l}\text { mice } \\
10 \mathrm{mg}\end{array}$} \\
\hline & $29,39(b)$ & 41 , & $65\left(^{*}\right)$ & 37 , & 42 & 38 , & $74\left(^{*}\right)$ \\
\hline 2 & $-3,-2$ & 1 , & 36 & 11 , & 21 & 35 , & $56\left(^{*}\right)$ \\
\hline 3 & 7,13 & 21 & 33 & 5 & 14 & 39 , & $38\left(^{*}\right)$ \\
\hline 4 & 2 & 18 & $52\left(^{*}\right)$ & 16 , & 40 & 33, & $n d(*)$ \\
\hline 5 & 6 & nd, & nd & 12 , & 17 & 41 , & $51\left(^{*}\right)$ \\
\hline (Mean) & (8) (13) & (20) & (46) & (16) & (27) & (37) & (55) \\
\hline
\end{tabular}

(a) $\mathrm{mg}$ protein in $0.2 \mathrm{ml}$ of isotonic cercarial extract injected intravenously

(b) percent increase (variation) in hemoglobin concentration at 5 and 10 minutes after challenge

(*) lethal shock

(nd) not done
Eight individual sera of 13-weeks infected mice were tested for the presence of IgG1 and IgE anti-schistosomal antibodies by PCA reactions respectively with 2 hours and 48 hours sensitization periods. The results obtained with the 2 hours sensitization periods are shown in Table IV. No discernible reactions were obtained with 48 hours sensitization periods, as the recipient mice developed generalized blueing reactions upon intravenous challenge with cercarial extracts and Evans blue dye. As shown in Table IV only 6 out of 8 sera were positive, and there was a wide variation in intensity of the reactions. These same $8 \mathrm{mice}$, used as serum donors were subsequently tested with cercarial antigens intravenously and the levels of histamine released to their blood assayed as in Table I; no significant relationship was found between these levels of histamine release and the magnitude of PCA reaction shown in Table IV. Thus, mouse number 5 showed only a mo. derate release, whereas mouse number 6 showed a very strong release.

$$
\text { T A B L E IV }
$$

Intensity of passive cutaneous anaphylactic reaction with individual sera from 13 weeks - infected mice

\begin{tabular}{cc}
\hline Serum number & Intensity of PCA reaction (b) \\
\hline 1 & + \\
2 & + \\
3 & + \\
4 & ++++ \\
5 & ++++ \\
6 & - \\
7 & - \\
\hline
\end{tabular}

(a) Sensitization (2 hours) with $1 / 10$ dilution of sera from 13-weeks infected mice; $0.03 \mathrm{ml}$ per skin site; challenge with $1 \mathrm{mg}$ cercarial antigen in $0.5 \%$ Evans blue dye (b) $\mathrm{mm}$ of blue areas: $+=5$; $++=10 ;++++=$ lar. ger than $20 \mathrm{~mm}$

\section{DISGUSSION}

Intravenous injection of cercarial or schistosomula extracts into either normal mice or mice infected 4-weeks before, fail to evoke the release of histamine to the blood. On the other hand, the same extracts evoked moderate to very strong histamine release when injected into mice sensitized 10-13-weeks before by either bisexual or unisexual schistosome infections (Table I).

The small number of experiments conduct. ed with peritoneal mast cells indicated that 
MOTA-SANTOS, T. A.; OLIVEIRA, A. F. S.; GERKEN, S. E. \& VAZ, N. M. - Anaphylaxis with Schistosoma mansoni extracts in normal and infected mice. Rev. Inst. Med. trop. São Paulo 27:179-185, 1985.

sensitization is stronger in the late phases of infection, and that cercarial extracts, as compared with soluble egg antigen or worm tegument extract, 'were more efficient histamine releasers. The concentrations of protein necessary to evoke significant histamine release from mast cells (Table II) were rather elevated when compared to the effective concentrations of purified proteins, such as ovalbumin 22 or the molar concentrations of hapten-conjugates of poly. 1-lysines of different molecular sizes ${ }^{26}$, respectively in ovalbumin or hapten-sensitized animals. This is probably a reflection of the great heterogeneity of the extracts, which are prepared by homogeneization of whole organisms. Fractionation of these extracts, which is now under way in our laboratory, will possibly reveal that different components vary in their sensitizing ability. Experiments not shown in the tables performed with animals infected 4 to 13 weeks before the tests showed that moderate to small rates of sensitization are present a 5 -weeks of infections. and moderate to strong sensitization is invariably present at 6-weeks after infection. Thus, the development of sensitization, as revealed by the release of histamine from peritoneal mast cells upon incubation "with cercarial extracts is coincident with the appearance of resistance to reinfection, which appears at 6-weeks and is more or less stable between 6-15 weeks of infection ${ }^{8}$. The period between 4 and 6-weeks, of infection is therefore crucial for the development of sensitization and immunity. This might depend on host factors, parasite factors or an interaction between them. Among the factors dependent on the parasites, the period between 4 and 6 weeks, is marked by the initiation of egg production 5 and secretions 10 of egg antigens, which might influence the processes of sensitization and immunity. However, as indicated in Table $I$, sensitization is present at 10-weeks in animals submitted to unisexual (male) infections, in which no eggs are produced. Sensitization, therefore, may be produced in the absence of egg antigens.

An observation made during the histamine assays on guinea pig ileum preparations was the elicitation of typical Schultz-Dale contractions following the first contacts with schistosome antigens present in mouse blood samples, probably resultant from cross-reacting sensitization with worms naturally infecting the gui- nea pigs. These natural infections have been previously revealed to be at the basis of the so-called "anaphylactoid" reactions of normal guinea pigs to injections of Ascaris extracts ?. As soon as this effect was noted in our experiments, the guinea pig ileum preparations were previously desensitized by exposure to whole body extracts of Paraascaris equorum, after which no contractions were observed by direct exposure to schistosome extracts, or antigencontaining mouse blood samples.

Similar problems were faced during the in vivo experiments measuring the hemoconcentration developing after intravenous injection of cercarial extracts. Although cercarial ex tracts failed to release histamine to the blood of normal mice when injected in low doses $(0.5$ - $0.6 \mathrm{mg}$, Table I) they evoked toxic symptoms when injected in higher doses; doses of $10 \mathrm{mg}$ per mouse actually killed two out of five normal mice. Nevertheless, the symptoms and the magnitude of the hemoconcentration observed in infected mice, "were significantly more pronounced. After these experiments were performed infections with Hymenolepis nana and Siphacia oblevata were detected in some animals in our mouse colonies; the former is now totally erradicated, but the latter seems rather difficult to eliminate ${ }^{14}$.

The sensitization of mouse mast cells by homologous IgGl antibodies is easily removed by simple saline washings, whereas the sensitization by mouse IgE antibodies is firmly established and, if anything, increases when the cells are washed ${ }^{29}$. Therefore, the results shown in Table II may be taken as presumptive evidence for the existence of IgE antibodies on mast cells of infected mice. On the other hand, our attempts to demonstrate antibodies by passive cutaneous anaphylaxis, although successful for IgGl antibodies ( 2 hours sensitization periods) in 6 out of 8 sera, failed to detect $\operatorname{IgE}$ antibodies (48 hours sensitization periods) because most of the recipient mice developed generalized blueing reactions, probably resultant from the diffusion of IgGl antibodies from the skin sites.

\section{RESUMO}

Anafilaxia desencadeada por extratos de Schistosoma mansoni em camundongos normais e infectados 
MOTA-SANTOS, T. A.; OLIVEIRA, A. F. S.; GERKEN, S. E. \& VAZ, N. M. - Anaphylaxis with Schistosoma mansoni extracts in normal and infected mice. Rev. Inst. Med. trop. São Paulo 27:179-185, 1985.

Métodos em geral utilizados para o estudo de reações anafiláticas desencadeadas por antígenos proteicos - tais como: determinaçãò da liberação de histamina para o sangue, hemoconcentração, liberação de histamina de mastócitos da cavidade peritoneal e reação de anafilaxia passiva cutânea (PCA) - foram usados para investigar alguns aspectos da anafilaxia a antígenos do Schistosoma mansoni. Liberação de histamina para o sangue e taxas significativas de hemoconcentração foram provocadas pela injeção endovenosa de extratos de cercária ou de esquistossômulos em camundongos infectados (10-13 semanas após infecção). Antígenos de cercária, de esquistossômulos, de tegumento de verme adulto e antígeno solúvel de ovo desencadearam a liberação de histamina de mastócitos coletados da cavidade peritoneal de camundongos cronicamente infectados. Reação de PCA com 2 horas de sensibilização $\left(\operatorname{IgG}_{1}\right)$ foi detectada em 6 de 8 soros testados, provenientes de camundongos esquistossomóticos crônicos. Nenhuma reação de PCA com 48 horas de sensibilização ( $\operatorname{IgE}$ ) foi detectada nestes mesmos soros. Ainda que IgE não tenha sido detectada na circulação pela técnica de PCA, os resultados indicam que camundongos infectados contém IgE ligada a seus mastócitos.

\section{ACKNOWLEDGEMENTS}

We thank Mr. José de Souza Filho and Mrs Rita de Cássia Soares França for technical assistance. We are indebeted to the Grupo Interdepartamental de Estudos sobre Esquistossomose (GIDE) for furnishing the cercariae used in these investigations. This work was supported by grants of Conselho Nacional de Desenvolvimento Científico e Tecnológico (CNPq), PIDE: 40.2070/80, 40.3806/82, 40.3809/82 and FINEP - Bioquímica n. ${ }^{0219) .}$

\section{REFERENCES}

1. BARTH, E. E. E.; JARRET, W. F. H. \& URQURHART, G. M. - Studies on the mechanism of self-cure reactions in rat infected with Nippostrongylus brasiliensis. Immunol. 10: 459-464, 1965.

2. BERALDO, W. T.; DIAS DA SILVA, W. \& PUDLES, J. - Antigenic properties of purified fractions from Ascaris lumbricoides var. suum on naturally-sensitized guinea pigs. Brit. Pharmacol. 17: 236-247, 1961.

3. BERGMAN, R. K. \& MUNOZ, J. - Circulatory collapse in anaphylaxis and histamine toxicity in mice. Immunol. 95: 1-8, 1965.
4. BOUT, D.; DESSAINT, J. P.; DUPAS, H.; YARZABAL, L. \& CAPRON, A. - Characterization of allergens in Schistosoma mansoni, Fasciola hepatica and Echino. coccus granulosus. Ann. Immunol. (Inst. Pasteur) 128c: 687-698, 1977

5. ERENER, Z. - Observações sobre a infecção do camundongo pelo Schistosoma mansoni. Rev. Bras. Med. Mal. Doenças Trop. 8: 5is5-575, 1956.

6. CAPRON, A.; BIGUET, J.; VERNES, A. \& AFCHAIN, D. - Structure antigenique des helminthes. Aspects Immunologiques des Relations Hôte-parasites. Path. Biol. (Paris) 16: 121-138, 1968.

7. DESSAINT, J. P.; CAPRON, M. ; BOUT, D. \& CAPRON, A. - Quantitative determination of specific IgE antibodies to schistosome antigens and serum IgE levels in patients with schistosomiasis (Schistosoma mansoni or Schistosoma haematobium). Clin. Exp. Immunol. 20: 427-436, 1975 .

8. GERKEN, S. E.; MOTA-SANTOS, T. A.; VAZ, N. M.; CORREA-OLIVEIRA, R.; DIAS DA SILVA, W. \& GAZ. ZINELLI, G. - The involvement of mast cells and vasoactive amines in the recovery of schistosomula of Schistosoma mansoni through mouse skin. Brazilian J. Med. Biol. Res. (in press).

9. GUSMAO, R.; STANLEY, A. M. \& OTTESEN, E. A. - Brugia pahangi: Immunologic evaluation of the differential susceptibility to filarial infection in inbred Lewis rat. Exp. Parasit. 52: 147-159, 1981.

10. HANG, L. M.; WARREN, K. S. \& BOROS, D. L. Schistosoma mansoni: antigenic secretion and the etio logy of egg granulomas in mice. Exp. Parasit. 35: 288-298, 1974.

11. HILLYER, G. V. - Immunoprecipitins in Schistosoma mansoni infections. IV Human infections. Exp. Parasit. 25: 376-381, 1969.

12. IFF, E. T. \& VAZ, N. M. - Similarity of shock induced by histamine-serotonin mixtures and passive anaphylaxis. Int. Arch. Allergy 30: 313-322, 1966.

13. KUSEL, J. R. - Protein composition and protein synthesis in the surface membranes of Schistosoma mansoni. Parasitology 65: 55-69, 1972.

14. LANE-PETER, W. \& PEARSON, A. E. G. - In The Laboratory Animal Principles and Practice. New York, Academic Press, 1971, p. 89

15. LEVINE, B. B. \& VAZ, N. M. - Effect of combination of inbred strains, antigen and antigen dose on immune responsiveness and reagin production in the mouse. Int. Arch. Allergy 39: 156-171, 1970.

16. LOWRY, O. H.; ROSEBROUGH, N. J.; FARR, A. L. \& RANDALL, R. J. - Protein measurement with the Folin phenol reagent. Biol. Chem. 193: 265-275, 1951.

17. MOTA, I.; SADUN, E. H. \& GORE, R. W. - Homocytotropic antibody response in mice infected with 
MOTA-SANTOS, T. A.; OLIVEIRA, A. F. S.; GERKEN, S. E. \& VAZ, N. M. - Anaphylaxis with . Schistosoma mansoni extracts in normal and infected mice. Rev. Inst. Med. trop. São Paulo 27:179-185, 1985.

Schistosoma mansoni: comparison with the response following Trichinella spiralis infection. Exp. Parasit. 24: 251-258, 1959.

18. MOTA-SANTOS, T. A.; TAVARES, C. A. P.; GAZZINELLI, G. \& PELLEGRINO, J. - Immunosuppression mediated by adult worms in chronic schistosomiasis mansoni. Am. J. Trop. Med. Hyg. 26: 727-731, 1977.

19. MURRAY, M. - Secretory antibody and local immuni. ty. Proc. Royal Soc. Med. 65: 659-662, 1972.

20. MUSOKE, A. J.; WILLIAMS, J. F. \& LEID, R. W. Immunological response of the rat to infection with Taenia taeniformis. VI Role of immediate hypersensitivity in resistance to reinfection. Immunol. 34: 565570-1978.

21. OGILVIE, B. M.; SMITHERS, S. R. \& TERRY, R. J. - Reagin-like antibodies in experimental infections of Schistosoma mansoni and the passive transfer of resistance. Nature 209: 1221-1223, 1966.

22. PROUVOST-DANON, A.; PEIXOTO, J. M. \& JAVIERRE, M. Q. - Antigen-induced histamine release from peritoneal mast cells of mice producing reagin-like antibodies. Immunol. 15: 271-286, 1968.

23. RAMALHO-PINTO, F. J.; GAZZINELLI, G.; HOWELLS, R. E.; MOTA-SANTOS, T. A.; FIGUEIREDO, E. A. \& PELLEGRINO, J. - Schistosoma mansoni: defined system for stepwise transformation of cercariae to schistosomula, in vitro. Exp. Parasit. 36: 360-372, 1974.
24. ROSSEAUX-PREVOST, R.; CAPRON, M.; BAZIN, H. \& CAPRON, A. - IgE in experimental schistosomiasis. II. Quantitative determination of specific IgE antibodies against Schistosoma mansoni. A follow-up study of two strains of infected rats. Correlation with protective immunity. Immunol. 35: 33-39, 1978.

25. SADUN, E. H. \& GORE, R. W. - Schistosoma mansoni and Schistosoma haematobium: Homocytotropic reaginlike antibodies in infections of man and experimental animals. Exp. Parasit. 28: 435-449, 1979.

26. VAZ, N. M. - Anaphylactic sensitization of mouse tissues with $\operatorname{IgE}$ and reaginic antibodies. In Biochemistry of the Acute Allergic Reaction. Oxford, Blackwell, 1972, p. 91.

27. VAZ, N. M.; IFF, E. T. \& PEIXOTO, J. M. - Histamine release to the blood during anaphylaxis in mice. Int. Arch. Allergy 30: 2s8-280, 1966.

28. VAZ, N. M. \& OVARY, Z. - Passive anaphylaxis in mice with homologous antibodies. III. Release of histamine from mast cells by homologous antibodies. J. Immunol. 100: 1014-1019, 1968.

29. VAZ, N. M. \& PROUVOST-DANON, A. - Behavior of mouse mast cells during in vitro anaphylaxis. Prog. Allergy 13: 111-173, 1969.

Recebido para publicação em 4/4/1984. 